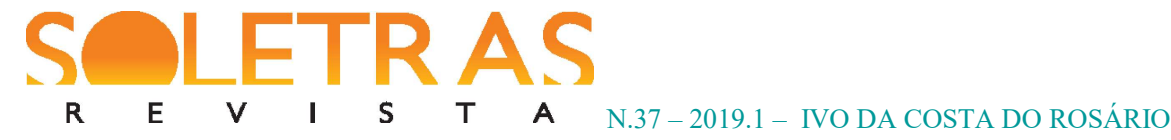

\title{
Interview with Graeme Trousdale
}

Ivo da Costa do Rosário ${ }^{1}$

\begin{abstract}
Graeme Trousdale is professor of Linguistics and English Language at the School of Philosophy, Psychology and Language Sciences, in The University of Edinburgh. He is Master of Science (University of Edinburgh), Doctor of Philosophy (University of Edinburgh) and Bachelor of Arts (University of Manchester). His main research interests involve the fields of constructionalization and constructional changes, English historical Linguistics and Cognitive Linguistics, especially construction grammar. In this interview the researcher discuss several theoretical questions, as constructionalization and constructional changes in synchronic perspective, schematic levels of a construction, functional domain, function and meaning, methodology, constructional variation, atomic constructions and finally challenges, weaknesses and future prospects of the constructionalization model.
\end{abstract}

Keywords: Graeme Trousdale. Linguistics. Constructionalization.

Soletras: Is it possible to apply constructionalization studies and constructional changes to essentially synchronic perspective works? ${ }^{2}$

In my view, a book like Traugott and Trousdale (2013) is a book about language change primarily (see further my response to your last question), and therefore its focus is diachrony, not synchrony. But as is well known, synchronic variation in a language is very often intimately connected with patterns of change, wherein some changes may have progressed more rapidly or in a slightly different way in the varieties spoken by one subpart of the network of language users than in other subparts. So one could observe a set of patterns at any given synchronic point in the history of a language, and try to use some of the principles of work in constructional change to explain why those patterns have the particular shape they do.

It is also possible to use some of the concepts adopted in work on constructionalization and constructional changes in work on synchronic variation. Indeed, some of the dimensions of constructional change (such as change in the generality/schematicity, productivity and

\footnotetext{
${ }^{1}$ Doutor em Letras Vernáculas (Língua Portuguesa) pela UFRJ e doutor em Letras (Estudos Linguísticos) pela UFF. Atualmente é docente de língua portuguesa do Instituto de Letras da UFF e docente permanente do Programa de Pós-graduação em Estudos de Linguagem da UFF.

${ }^{2}$ Thanks to Tharlles Lopes Gervásio (UERJ) for the translation of all the questions in this interview.
} 
compositionality of a construction) were drawn from work on essentially synchronic systems (LANGACKER, 2005). In other words, the concepts from construction grammar can be applied equally to synchronic and diachronic studies: but the diachronic studies will be concerned with comparing how various properties of constructions appear to have changed in the historical record. Recent research in diachronic construction grammar has particularly made use of large corpora like the Corpus of Historical American English (COHA; DAVIES 2010) in order to provide a quantitative analysis of changes (as well as mining such corpora for examples in a qualitative account).

Another issue is that, just like earlier concepts such as grammaticalization and lexicalization, constructionalization is not something that speakers and writers consciously do. All they (along with hearers/writers) do is analyse, in order to produce or perceive a formal string that is associated with a meaning. Historical linguists can observe constructionalization (at least in the way the term is used by Traugott and Trousdale 2013) by observing that a form $_{\text {new }}-$ meaning $_{\text {new }}$ conventional unit has arisen in the textual record. The same holds true for constructional change, in which one aspect of form or meaning has come to vary over time.

Soletras: Do inheritance relations also occur at more schematic levels of a construction? Could you give us an example?

Yes, inheritance can be shown to occur at more schematic levels in the constructional network. Hopefully an example will make things clear. Imagine a speaker utters the words in (1) below:

(1) She let the cat out of the bag and left.

This has two possible interpretations. One treats the first verb phrase as compositional (in a situation in which a speaker reports that a woman let a real cat out of a bag), the other as idiomatic and thus reduced in compositionality (where to let the cat out of the bag means 'to reveal the secret'). Which of these two readings is the one the speaker intends is only going to be understood given the rest of the context of the discourse. In other words, our resolution of which of the meanings (compositional vs. non-compositional) is most likely is associated with the actual use of the expression in a particular linguistic context, i.e. as a token of language use. But in either case - whether the hearer interprets the expression as compositional or not, in context - the fact that both the idiomatic and the non-idiomatic expression can be co- 


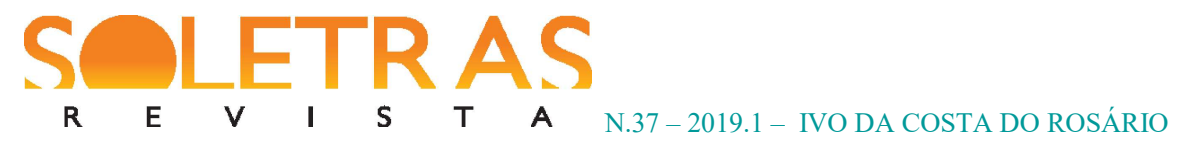

ordinated with another verb phrase (here left) is a property associated with the fact that let the cat out the bag is a VP, irrespective of its meaning. In other words, both the idiomatic and the non-idiomatic structure inherits the capacity to co-ordinate with another VP from the fact that it itself is a VP, and this is not an issue of the specific context of use.

Soletras: How can the concept of functional domain (GIVON) be compatible with a constructional approach to grammar?

I take the notion of functional domain to be the way in which speakers use particular forms in order to express procedural functions. In this sense, it is very compatible with various strands of constructional grammar which are essentially functionalist in orientation. Often functional domains are especially relevant for research in typology, and therefore is concerned with properties of languages. One very clear example of such a position comes from Miestamo (2007, p. 293), who writes "The terms functional domain goes back to Givón (1981), and can be characterized as any domain of related (semantic or pragmatic) functions that (one or more) language(s) encode with the formal means they possess". Some versions of construction grammar take a particular typological focus (e.g. Croft 2001), while other are more concerned with psycholinguistic properties of language as they are used by individual speakers (e.g. GOLDBERG 1995, 2006). This strikes me as important because it brings into focus the place of the individual speaker in discussions about language. For me, languages don't encode anything; only speakers encode. This may seem like a trivial observation, and I am aware that the term languages is often used metonymically to mean 'speakers of languages' but I see it as important because language changes begin with speaker innovation.

That said, I believe functionalism and all usage-based variants of construction grammar to share the common view that much of syntactic structure is emergent over instances of language use; in other words, syntax evolved because it aids communication.

Soletras: What are the similarities and differences between the concepts of function (CRYSTAL, 1988; NICHOLS, 1984) and meaning (CROFT, 2001)?

As I understand Nichols (1984), the focus there is on what properties distinguish functional, formal and structuralist approaches to the study of language. Functionalist 
approaches are concerned, among other things, with language processing, cognition and discourse structure (see CROFT 2015), and many studies in cognitive linguistics, psycholinguistics and sociolinguistics could be seen as functionalist. It is also the case that much work in grammaticalization has been seen as functionalist - so in one sense, functionalism is a way of doing work in language.

But when you ask what the difference between function and meaning is, it may be you are asking about individual linguistic items, or indeed texts. Sometimes the difference between function and meaning is rather clear: in (2), one can talk of the (grammatical) function of the NP the man as the subject of the clause, but that is not at all what the meaning of the man is.

(2) The man is riding a bicycle.

Similarly, a text like a recipe has a clear function (it has been created to enable someone to prepare food, typically), but here function is used differently again; and it would be unusual to talk about a recipe as having a meaning. Part of the problem is that the concepts 'meaning' and 'function' are themselves highly general, and so comparing and contrasting the two is no easy task.

Soletras: In methodological terms, what is the importance of the quantitative approach in researches guided by the constructional view of grammar?

I think this is an exceptionally important part of work in certain domains of construction grammar. Generally speaking, the quantitative turn in linguistics has been gathering pace for some time now, and is reaching beyond traditional domains such as sociolinguistics and psycholinguistics into formal approaches to syntax. For usage-based construction grammar, much has been made of frequency and its effects on linguistic structure (see particularly the work of JOAN BYBEE, MARTIN HILPERT, STEFAN GRIES, and ANATOL STEFANOWITSCH, among others). Some recent work in diachronic construction grammar (e.g by PEREK 2016 and PIJPOPS and VAN DE VELDE 2016, as mentioned above) has brought to light very interesting findings with regard to the structure of the constructional network (how one construction impinges on another), and the relationship 


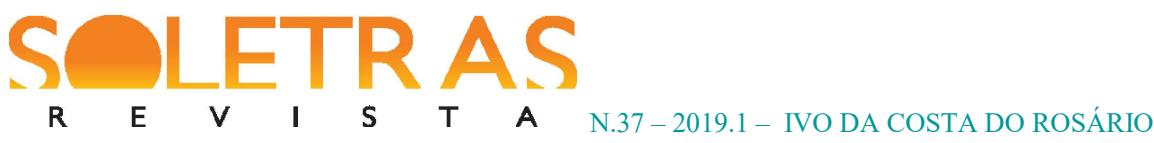

between schematicity and productivity in change. This has been enabled by ever larger corpora of natural language, combined with increasingly sophisticated statistical methods.

Soletras: Based on the principle of non-synonymy of grammatical form (GOLDBERG, 1995), is it possible to postulate the existence of constructional variation? How do these ideas fit together?

While I think it is often the case that variation in form will suggest some variation in meaning, recent work in constructional variation and change has problematized the issue of isomorphism substantially. Work by Hendrik De Smet (e.g DE SMET 2010), Lauren Fonteyn (e.g. FONTEYN 2016) and Freek Van de Velde (e.g. VAN DE VELDE 2014), for instance, has looked in some detail at the "many-to-many" relations that exist in the constructional network. Indeed, a true network approach to language structure often reveals how words and constructions involve multiple inheritance. Again, this is supported by work on language change (see the discussion in VAN DE VELDE, DE SMET and GHESQUIÈRE 2013) and in psycholinguistics (see the discussion of inheritance in HUDSON 2007, for instance).

Soletras: In grammaticalization studies, there is a great deal of literature on linguistic change and grammaticality of individual language items, such as discourse markers, argumentative operators, connectives etc. In the context of the constructional approach to grammar, considering that these items can also be interpreted as constructions, how can we apply the parameters of compositionality, schematicity and productivity to these elements?

I think here the notion of network is again important. The individual language items that you mention also form part of a network of related items. In selecting a particular discourse marker - for example, an intersubjective clause-final marker to invite the addressee to confirm, deny or otherwise contribute to the discourse relating to a statement that has just been made, speakers of English have a number of choices:

$$
\text { You're coming, \{aren't you/right/yes/no/...\}? }
$$

Each of these individual choices has their own distinct properties, both formal and functional, and each has a relation to the clause that precedes it. My view of the recent research in diachronic construction grammar is that an understanding of the nodes of the 


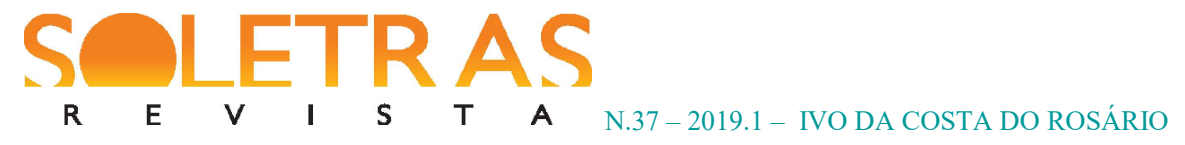

network and the links between nodes of the network is where we will make most progress in explaining patterns of language change.

In terms of the parameters you mention, again we need to think about change in the degree of compositionality, productivity and schematicity involved. Consider for instance the form innit, as another member of the set of discourse markers listed in the brackets in (3). This is a relatively non-standard form, and use of innit as a tag question is often stigmatized in English. It is less compositional with respect to the more standard reverse polarity tagquestion (which in (3) is aren't you), because it appears to be used as a chunk, and for some speakers of English, can appear whether the subject of the declarative clause is third-person singular or not, as exemplified in (4):

(4) $\quad\{$ It's/you're/she's/... $\}$ nice, innit?

Its frequency of use appears to be increasing over time (PALACIOS MARTÍNEZ 2015), and it also appears to have generalized its function and has undergone host class expansion. Thus while it is certainly possible to talk about individual changes, recent work in diachronic construction grammar is focused much more on sets of changes, and on the multiple links that items often display in the language network.

Soletras: In summary, what are, in your view, the challenges, weaknesses and future prospects of the constructionalization model and constructional changes?

In 2013, (at least) two books on the subject of constructional change appeared: one by Martin Hilpert (HILPERT 2013), and the other co-authored by Elizabeth Traugott and me (TRAUGOTT and TROUSDALE 2013). The main difference between the two, in my view, is this: Hilpert's book is quantitative, and comes at issues relevant to diachrony from a corpusbased, cognitive construction grammar perspective; Traugott and Trousdale's contribution is qualitative, and comes at issues relevant to cognitive construction grammar from a diachronic perspective $^{3}$. The challenge is to build on both of these approaches simultaneously, taking quantitative and qualitative analysis equally seriously. Much of the work that is being carried out in research centers for linguistics at Leuven, Ghent and Antwerp in Belgium (among other

${ }^{3}$ For a critical review of the ideas presented in Traugott and Trousdale (2013), see Börjars, Vincent and Walkden (2015). 


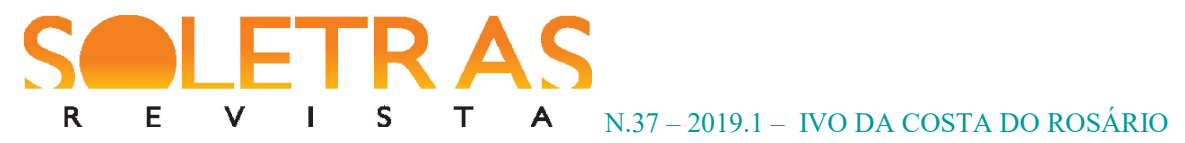

places) has been doing so for some time, and continues to do so. An additional prospect for future work is to build more on the network approach to language structure, and the similarities that exist between construction grammar and Word Grammar, as discussed in my preface to the questions above. Another interesting prospect is to continue to develop work in diachronic construction grammar in languages that are typologically different to English: much - but by no means all - of the work that has been done so far in diachronic construction grammar has tended to focus on Germanic languages. It is exciting to see all the work on constructional variation and change in Portuguese being carried out in various universities in Brazil!

\section{Last words of the interviewed}

Thank you for your excellent questions. They have given me a great deal to think about, as I believe what you've asked gets to the heart of a number of interesting issues in current thinking about diachronic construction grammar. Some of these problems are not new (for instance, establishing the precise relationship between meaning and function), but they are all very important in a theory of linguistic knowledge which foregrounds conventional pairings of form and meaning.

Particularly compelling, and equally revealing, are the insights from very recent quantitative approaches to constructional variation (e.g. PEREK 2016, PIJPOPS and VAN DE VELDE 2016) which have shed new light on key issues like the relationship between frequency and productivity, or the way in which constructions that are similar in form and meaning (i.e. 'close' in the constructional network) may influence each other, and how these things help us to understand the processes of language change.

As will be clear from my response to your last question, one of the most promising avenues of research in diachronic construction grammar is investigating the shape of the constructional network, and how it changes.

There is a real problem in trying to articulate precisely what the constructional network looks like, given its multidimensionality, but even with these representational limitations, it is clear we can use some insights from accounts of networks in terms of the relationship between linguistics and cognition (see for example HUDSON 2007) to see how 


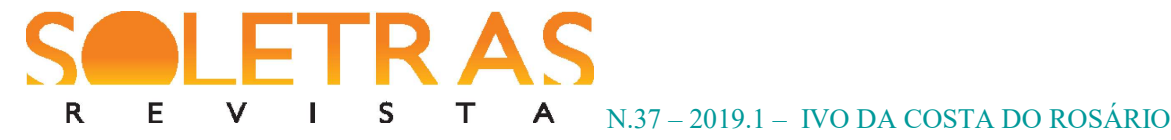

such insights may be adopted for purposes associated with developing a full account of the nature of constructional change.

The notion of the language network is something that cognitive Construction Grammar has inherited from other members of the 'cognitive linguistics' family, such as Cognitive Grammar (LANGACKER, 1987, 2008) and Word Grammar (HUDSON, 1990, 2007; GISBORNE, 2010). Nikolas Gisborne in particular has shown in his research the ways in which Word Grammar interfaces with historical linguistics (GISBORNE, 2011) and construction grammar (GISBORNE, 2008, 2010), so there is great potential for new directions in research which bring cognitive Construction Grammar and Word Grammar closer together.

\section{References}

BÖRJARS, Kersti; VINCENT, Nigel; WALKDEB, George. 2015. On constructing a theory of grammatical change. Transactions of the Philological Society 113, p. 363-382, 2015.

CRYSTAL, David. The Cambridge Encyclopedia of Language. New York: Cambridge University Press, 1988.

CROFT, William. 2001. Radical Construction Grammar: Syntactic Theory in Typological Perspective. Oxford: Oxford University Press, 2001.

. Functional approaches to grammar. In: WRIGHT, James D. (Ed.)International

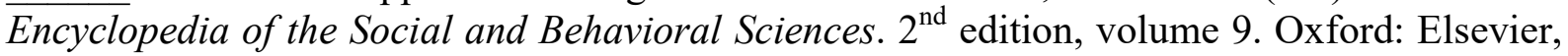
p. 470-475, 2015.

DAVIES, Mark. The Corpus of Historical American English (COHA): 400 million words, 1810-2009. Available online at http://corpus.byu.edu/coha/, 2010.

DE SMET, Hendrik. Grammatical interference. In: TRAUGOTT, Elizabeth Closs; TROUSDALE, Graeme (Eds.) Gradience, Gradualness and Grammaticalization. Amsterdam: Benjamins, p. 75-104, 2010.

FONTEYN, Lauren. Categoriality in language change: the case of the English gerund. PhD thesis, KU Leuven, 2016.

GISBORNE, Nikolas. Dependencies are constructions: a case study in predicative complementation. In: Graeme Trousdale and Nikolas Gisborne, eds. Constructional Approaches to English Grammar. Berlin: Mouton de Gruyter, p. 219-255, 2008.

. The Event Structure of Perception Verbs. Oxford: Oxford University Press, 2010. 
Constructions, Word Grammar and grammaticalization. Cognitive Linguistics 21, p. 155-182, 2011.

GIVÓN, T. Typology and functional domains. Studies in Language 5: p. 163-193, 1981.

GOLDBERG, Adele E. Constructions: A Construction Grammar Approach to Argument Structure. Chicago: University of Chicago Press, 1995.

. Constructions at Work: The Nature of Generalization in Language. Oxford: Oxford University Press, 2006.

HILPERT, Martin. Constructional change in English: developments in allomorphy, wordformation and syntax. Cambridge: Cambridge University Press, 2013.

HUDSON, Richard A. English Word Grammar. Oxford: Blackwell, 1990. 2007.

Language Networks: The New Word Grammar. Oxford: Oxford University Press,

LANGACKER, Ronald W. Foundations of Cognitive Grammar: Theoretical Prerequisites, Vol. 1. Stanford: Stanford University Press, 1987,

Construction Grammars: Cognitive, radical, and less so. In: Ruiz de Mendoza Ibanez, Francisco J., and M. Sandra Pena Cervel, eds. Cognitive Linguistics: Internal Dynamics and Interdisciplinary Interaction. Berlin: Mouton de Gruyter, p. 101-159, 2005.

Cognitive Grammar: A Basic Introduction. Oxford: Oxford University Press, 2008.

MIESTAMO, Matti. Symmetric and asymmetric encoding of functional domains, with remarks on typological markedness. In.: MIESTAMO, Matti; WÄLCHLI, Bernhard (Eds.)New Challenges in Typology: Broadening the Horizons and Redefining the Foundations. Berlin: Mouton De Gruyter, p. 293-314, 2007.

NICHOLS, Johanna. Functional theories of language. Annual Review of Anthropology 13, p. 97-117, 1984.

PALACIOS MARTÍNEZ, Ignacio. Variation, development and pragmatic uses of innit in the language of British adults and teenagers. English Language and Linguistics 19: 383-405, 2015.

PEREK, Florent. 2016. Using distributional semantics to study syntactic productivity in diachrony: a case study. Linguistics 54, p. 149-188, 2016.

PIJPOPS, Dirk; VAN DE VELDE, Freek. Constructional contamination: how does it work and how do we measure it? Folia Linguistica 50, p. 543-581, 2016.

TRAUGOTT, Elizabeth Closs; TROUSDALE, Graeme. Constructionalization and Constructional Changes. Oxford: Oxford University Press, 2013. 


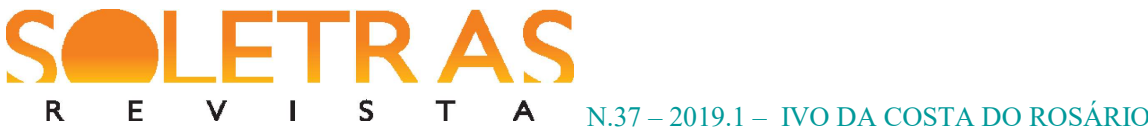

VAN DE VELDE, Freek. Degeneracy: the maintenance of constructional networks. In: Ronny Boogaart, Timothy Colleman and Gijsbert Rutten, eds. Extending the Scope of Construction Grammar. Berlin: De Gruyter, 141-180, 2014.

;DE SMET, Hendrik; GHESQUIÈRE, Lobke. On multiple source constructions in language change. Studies in Language 37, p. 473-489, 2013.

\section{Entrevista com Graeme Trousdale}

Resumo: Graeme Trousdale é professor de Linguística e Língua Inglesa na Faculdade de Filosofia, Psicologia e Ciências da Linguagem da Universidade de Edimburgo. É mestre em Ciências (Universidade de Edimburgo), Doutor em Filosofia (Universidade de Edimburgo) e Bacharel em Artes (Universidade de Manchester). Seus principais interesses de pesquisa envolvem os campos da construcionalização e mudanças construcionais, Linguística histórica da língua inglesa e Linguística Cognitiva, especialmente a Gramática deConstruções. Nesta entrevista, o pesquisador discute várias questões teóricas, como a construcionalização e mudanças construcionais em perspectiva sincrônica, níveis esquemáticos de uma construção, domínio funcional, função e significado, metodologia, variação construcional, construções atômicas e, finalmente, desafios, dificuldades e perspectivas futuras do modelo da construcionalização.

Palavras-chave: Graeme Trousdale. Linguística. Construcionalização.

Recebido em: 31 de julho de 2018.

Aceito em: 16 de novembro de 2018. 